\title{
Gastbeitrag
}

Caroline Wiedmer*

\section{Forced Entanglements:}

Stories of Expulsion, Sovereign Power and Bare Life 
Abstract: This article explores the contemporary practice of forced detainment and expulsion in Switzerland from two distinct perspectives: the 1995 law on coercive measures that first introduced the practice in Switzerland, as well as the cultural context that led to its constitution, and the documentary Le vol spécial by Fernand Melgar, made some fifteen years after the law was first introduced, which records the law's consequences for the daily lives of rejected asylum seekers awaiting expulsion. Using Giorgio Agamben's theoretical work on the states of exception and bare life, I seek to uncover what I call the narrative of expulsion, arguing that narrative politics operates on a number of interrelated levels not only to shape the context and practice of forced expulsion that undergird the asylum politics in Switzerland, and other countries, today, but ultimately also to change the post-enlightenment narrative of the political subject and challenge the efficacy of the Human Rights regime the world over.

Keywords: Forced deportation; refugee politics; legal culture; human rights; Switzerland; Giorgio Agamben; Fernand Melgar; narrative politics; story of expulsion; asylum regime

* Caroline Wiedmer, Comparative Literary and Cultural Studies, Franklin University Switzerland

\section{Introduction}

On March 17, 2010, a Nigerian refugee by the name of Joseph Ndukaku Chiakwa died in the Ausschaffungsgefängnis, or deportation prison, at Zurich airport while being prepared for deportation on a so-called Sonderflug, or "special flight", to Nigeria. "Special flights" are used in Switzerland when individuals whose asylum requests have been denied, or who are found to be in Switzerland without proper papers, refuse to leave the country voluntarily. At the time of his death, Chiakwa had been subjected to a so-called level-IV deportation procedure, in which refugees have their hands and feet bound, are strapped into a chair, are made to wear a full face mask, and are then carried onto the flight in the chair. He died during this procedure. In the immediate wake of his death, all special flights were suspended by the State Secretariat for Migration, as it awaited the autopsy report. The Institute of Forensic Medicine at the University of Zurich, tasked with this autopsy, found that Chiakwa had begun a hunger strike two months previously upon being incarcerated in December of 2009. He had, it was found, suffered from an undetected heart problem, which, aggravated by the effects of the hunger strike and the anxiety of the deportation procedure, ultimately led to his death. These findings were announced on May 25, 2010, a little more than two months after the incident; two hours after the announcement, the Swiss State Secretariat for Migration lifted the suspension and began planning for the departure of the next Sonderflug. ${ }^{1}$

This article investigates the practice of detention and forced expulsion in Switzerland that led to Chiakwa's death in two overlapping texts: first, the so-called Bundesgesetz über die Zwangsmassnahmen im Ausländerrecht, ${ }^{2}$ or Federal Act on Coercive Measures in the Law Governing Foreign Nationals, enacted in 1995, which strengthened the legal basis for forced expulsion in Switzerland, and the historical context in which it was forged; and second, a documentary by Swiss filmmaker Fernand Melgar entitled Le vol special, from 2012, which records life in a detention centre for people slated for expulsion. They each offer distinct views, and distinct interpretations, of detention and forced expulsion, and their cul-

1 The human rights group Augenauf assembled a dossier on the case, which includes the original autopsy report by the Institute for Forensic Medicine at the University of Zurich, the report from pathology, the report submitted by Chiakwa's family's lawyer, a report from a cardiologist questioning the original autopsy report, and links to a number of newspaper articles. See http://www.augenauf. ch/dossiers/70-ausschaffungen/125-joseph-ndukaku-chiakwa-alias-alex-khamma.html, accessed on April 2, 2018. 2 See Art. 69-71, Federal Act on Foreign Nationals, https:// www.admin.ch/opc/en/classified-compilation/20020232/ index.html, accessed January 14, 2019. 
tural consequences. Because the perspectives are so disparate, epistemologically, ideologically and structurally, their confrontation brings to the fore the often invisible links among law, the cultural context in which it is created, and the actual practice it enables, all of which illuminate the implications of state control in the realm of Swiss asylum politics. Comparing these perspectives also reveals deep fissures in the master narratives that help us think our historical moment, not only in Switzerland but around the world. The overarching theoretical framework I employ to read the two texts, and the events surrounding them, is indebted to Giorgio Agamben's conceptualisation of states of exception, those extralegal regimes a sovereign power creates in the name of the public good, and to Agamben's ideas on the production of what he terms "bare life," or life deprived of all rights by such a power. Reading the law and the documentary film against one another in light of Agamben's theories helps illuminate not only the legal and documentary texts themselves, but also our understanding of the political practice at work in asylum regimes everywhere.

The politics of narrative is central to both the law and the documentary film I discuss here as case studies; the entire asylum process is informed by its entanglement with a number of legal, political and cultural levels. In addressing the intersections of the legal, documentary and theoretical texts, therefore, I underscore the narrative dimensions of the texts proper as a way to bring nuance not only to the legal processes and the documentary, and their interaction with one another, but also to our conception of the complex cultural mechanisms that shape the Swiss asylum regime, and by extension asylum regimes of many democracies. This framing of texts and cultural processes as narrative, in turn, reveals some of the more troublesome directions contemporary asylum politics is taking, not only in today's Switzerland, but across Europe and beyond. I argue that what I call the story of expulsion-which includes both the way we speak of expulsion and coercive measures in systems of asylum, and the conditions under which those who are slated for expulsion tell stories-is a narrative that threatens the humanitarian ideals on which 'Switzerland' depends. Indeed, the story of expulsion shows that the very notion of human rights is endangered the world over.
I begin with a discussion of the role of narrative in the asylum system, then move to Agamben's theoretical positions on sovereign power and his notions of "bios" and "zoe", and, related to them, of bare life. I then explore the legal proceedings in the early 1990s that culminated in the federal act on coercive measures, the law that made possible both the institution of the Ausschaffungszentrum, or deportation centre, and the institution of the so-called vol spécial, or special flight, that today takes on a central role in enforcing the decision to expel those who are not allowed to stay in Switzerland. Finally, I focus specifically on Melgar's film Le vol spécial as a document that not only shows many of Agamben's ideas on bare life in action, but also attempts to reveal the inmates' stories of expulsion by giving them a voice and an audience.

\section{Narrating the Story of Expulsion}

How is the asylum process shaped by narrative? From the asylum seekers' point of view, the process begins with the stories they tell upon arrival in a would-be host country: stories that explain how and why they fled their countries of origins, and how they arrived in the hoped-for host countries to apply for asylum. These stories are subsequently written down by case workers in refugee reception centres, along with notes on how the case workers interpret the refugees' stories; these reports are then followed by asylum decisions handed down by yet another set of officials, who base their own reports on these initial interpretations by case workers. In most cases, these last interpretations ultimately shape the way the refugees' stories, which set the process in motion in the first place, are to take their course. If, however, an asylum seeker appeals a decision, the story takes yet another loop, this time processed by the relevant courts, adding details along the way that include legal considerations until it lands once again on the doorstep of the would-be asylee, the product of multiple layerings, one story on top of the other, like a palimpsest. This relatively contained initial cycle of tellings and retellings passed on from refugees to administrators of various kinds, to legal experts and back, operates in its turn within a number 
of larger, informal story cycles, each following its own particular logic: information shared among refugees, and between refugees and traffickers, on what to include and what to omit in their stories in order to achieve asylum; stories told among case workers about what sounds authentic and what does not; stories told by the laws and regulations of the respective asylum regimes; and, finally, stories told about refugees in the larger culture: who they are, and what they potentially bring to, and take away from, the communities in which they hope to make a new life.

Each of these linked realms of storytellingthe personal, the bureaucratic, the legal, the political and the cultural-is informed by its own interests, by its own legal and moral codes, and by its own ideological underpinnings. And quite often, these linked narrative contexts are contradictory and controversial, occasionally at cross purposes, and yet making up a whole that determines the experience a refugee will have in a given country at a given time. Inscribed in these narrative contexts, too, at every level and in each realm, is the question of power: who gets to tell a story? Who is obliged to tell a story, and who is forbidden to? Whose interpretation is considered valid or suspect, true or false? What parameters are used to assess a story? Who gets to make that decision? Why are certain stories and voices amplified while others are dampened, like a radio turned down low to better hear the conversation in the room? And what is the role of the various identities at play in this hot tangle? To make things even more complicated, these questions about narrative never arise in a vacuum; they all have their own detailed backstories and political contexts, which have evolved, often over centuries, as different legal regimes have shaped their relation to its subjects, and as foreigners have been thought about, talked about, represented, rendered invisible or visible, legalised or criminalised, in theoretical, national and supranational contexts. And finally, there is the realm of silence, from whence stories are only rarely heard, and about which, we only rarely tell stories. This is the realm of expulsion.

The unpredictable moment of Chiakwa's death, and others since then, in the context of forced detention and deportations, is one of those rare moments in which the realm of expulsion, suddenly visible, revealed the fractures and strains in the narrative economy that Agnes Woolley calls "the asylum story"; ${ }^{3}$ it allows us to delve beneath this economy to read the violence that resides in the story of expulsion. These stories of expulsion linger, often unheard, in a distinct area of the asylum regime, in a realm to which humans are banned after their stories have been found to be unfit by the bureaucracy that steers the asylum system. These are stories that ordinarily lack an audience to listen, or a platform on which to be told. In that sense, they lack both addressees and agencies, rendering the storytellers themselves essentially voiceless, and position those trying to excavate the stories on contested ground. They are, finally, stories that reveal the ruptures and fractures in the human rights regime. Later in this article, we will revisit the news of Chiakwa's death from a somewhat different angle when it ploughs into the story line maintained in Le Frambois, the detention centre featured in the documentary Le vol spécial, leaving jagged edges in its account of purportedly smooth operations and laying bare the architecture of power that suffuses the entire asylum system. It asks questions about the master narrative featuring a modern political subject, the narrative vacuum surrounding the banned subject, and the disjunction between humanitarian values and those of a sovereign-in the case of Switzerland, both the Federal Council and the people-bent on constituting itself precisely by undermining those values: narratives all well-established over the course of more than a century in Switzerland, but now being gradually challenged.

\section{States of Exception and Bare Life: Giorgio Agamben's Homo Sacer}

Giorgio Agamben's Homo Sacer identifies the legally and socially dispossessed as a central hinge in the constitution of modern sovereign power. The dispossessed, in Agamben's telling, is the enigmatic figure of the homo sacer, or sacred

3 See, for an excellent article on the veracity claim in narratives in the asylum regime, Agnes Woolley (2017), Narrating the "Asylum Story": Between Literary and Legal Storytelling, Interventions, 19:3, 376-394, http://eprints.bbk. ac.uk/21157/1/21157.pdf, p. 5, accessed November 2019. 
man, from the archaic Roman law, who could be killed with impunity, but never sacrificed. His main goal, in a four-volume work, is to trace the mechanism of totalitarian ideologies in modernity around the key links he establishes between the sovereign, the sacred man and the ban, suggesting that sovereign forms of power in today's democracies are defined by their very ability to bring power to bear on subjects in their jurisdiction in a way that turns them into homines sacri, forced by the sovereign to lead what he terms bare lives-lives without recourse to sovereign protection. In Agamben's words, "the inclusion of bare life in the political realm constitutes the original-if concealed-nucleus of sovereign power. It can even be said that the production of a biopolitical body is the original activity of a sovereign power."4 In terms of narrative, the dominant story about law and the sovereign is turned on its head in this interpretation: rather than bringing justice to its subjects and safeguarding their rights, the sovereign's inherent identity rests on the power to suspend rights and to shape subjects as outcasts.

This figure of the outcast and the notion of bare life deserve a closer look. The homo sacer or "sacred man" in Roman law was a figure banned from society; sacred, not so much in a religious sense, but rather in the sense that he had been set aside, and accursed. Agamben deploys this figure as an allegory to develop Michel Foucault's theories of biopolitics, while further elaborating the notion of the state of exception, first articulated by the German legal scholar Carl Schmitt in the 1920s, during the Weimar Republic, and, in a different vein, after World War II in the context of decolonisation. ${ }^{5}$ Following Jean-Luc Nancy,

4 Giorgio Agamben, Homo Sacer: Sovereign Power and Bare Life, trans. by Daniel Heller-Roazen, Stanford: Stanford University Press, 1998, p. 6 (emphasis in the original). 5 In the early 1920s, Schmitt argued in Political Theology. Four Chapters on the Concept of Sovereignty that the application of legal norm presupposes social normality and cannot apply to emergencies or chaos. In fact he maintains in his early writing that continuing to apply law through the usual channels of jurisdiction and administration in a case of emergency would not only threaten to be haphazard and ineffective, but would prevent the emergency itself from being adequately addressed. Therefore, if it is true that the application of legal norm to an abnormal situation is no longer tenable, then a polity must be able to decide to suspend legal norm when warranted. To Schmitt, it then
Agamben sees the suspension of law as taking the form of a ban, in which what is to be banned "is delivered over to its own separateness, and at the same time, consigned to the mercy of the one who abandons it-at once excluded and included, removed and at the same time captured". ${ }^{6}$ A person who is abandoned by the law, he writes further, is "exposed and threatened on the threshold in which life and law, outside and inside, become indistinguishable."7 Thus, exposed by the structure of exception, the subject is conceptualised by Agamben as living a bare life-a notion that recuperates the distinction made by the ancient Greeks between bios and zoe, two terms that describe different dimensions of life, bios referring to the potentialities and possibilities of a life lived in the public realm, zoe to the simple, biological fact of life lived in private, in the home or oikos, beyond the interference of politics. ${ }^{8}$

Bare life, for its part, is not merely zoe, but moves between the simple, biological fact of life in private and bios, between the home and the public realm, its precise location determined in accordance with the needs of the sovereign power of any given state and in any given time; in Agamben's words: "...every society-even the

follows that a person or institution in a position to decide to suspend the law and to use extra-legal force to normalise the emergency situation is the sovereign. In a post-war work entitled Nomos of the Earth in the International Law of the Jus Publicum Europaeum, Schmitt's conceptualisation of the exception shifts somewhat. His focus during this time of intense debate over how formerly colonised lands are to be re-ordered is no longer on the fact that the ability to decide exception and to suspend normative law defines the sovereign, but instead shifts to consider what constitutes law and order in the first place. In his quest to make visible the intimate relationship between land and law, Schmitt returns to an originary understanding of order as constituted and sustained through the appropriation and division of land, territory and resources. This meaning, Schmitt argues, is captured in the word nomos, which contains three connotations: appropriation, distribution and production. This distribution of land results in what Schmitt has called the Ordnung and Ortung, or order and localisation, of land and habit, observing that "nomos is the immediate form in which the political and social order of a people becomes spatially visible." "Sovereign is he who decides on the exceptional case," Schmitt states famously at the very beginning of Political Theology.

6 Agamben, Homo Sacer, p. 110

7 Agamben, Homo Sacer, p. 28

8 Agamben Homo Sacer, p. 6 
most modern-decides who its sacred men will be. ${ }^{\prime \prime 9}$ And further to the notion of bare life:

... the decisive fact is that, together with the process by which exception everywhere becomes the rule, the realm of bare life-which is originally situated at the margins of the political order-gradually begins to coincide with the political realm, and exclusion and inclusion, outside and inside, bios and zoe, right and fact, enter into a zone of irreducible indistinction. ${ }^{10}$

No longer is the zone of indistinction to be found at the margin of a political commons; rather, the realms where people are forced to live bare lives are increasingly placed inside of communities. This quintessential zone of indistinction to Agamben is the Nazi concentration camp, representing to his mind "the very paradigm of political space at the point at which politics becomes biopolitics [...] in which power confronts nothing but pure life, without any mediation". ${ }^{11}$

Does this mean that the concrete spaces created in Switzerland by the law on coercive measures, or by the United States in Guantanamo Bay, can be compared to Auschwitz? No, not the concrete spaces themselves, nor the kind, breadth and depth of the perpetration. In fact, Agamben's proposition that Auschwitz be read as the paradigmatic space for an emerging sovereign order of exception seems to fly in the face of a widespread position that holds Auschwitz to be incomparable to anything that pre-exists or succeeds it. It is a position that sees the vastness of the suffering inflicted, the arbitrary, extreme, sustained cruelty of the camps, and the intentional system-

\section{Agamben, Homo Sacer, 139}

10 Agamben, Homo Sacer, p. 9

11 Homo Sacer, p. 171. The often quoted passage on the Nazi concentration camp as emblematic of modernity reads as follows: "When our age tried to grant the unlocalisable a permanent and visible localisation, the result was the concentration camp. The camp-and not the prison-is the space that corresponds to the original structure of the nomos. This is shown, among other things, by the fact that while prison law only constitutes a particular sphere of penal law and is not outside the normal order, the juridical constellation that guides the camp is martial law and the state of siege [...]. As the absolute state of exception, the camp is topologically different from a simple space of confinement. And it is this space of exception, in which the link between localisation and order is definitely broken, that has determined the crisis of the old 'nomos of the earth'." Homo Sacer, p. 20. atic genocide that underwrote them as nothing less than a caesura in civilisation: an event that, in the severity of its impact and depravity, could not be repeated. Indeed, as Anthony Downey notes,

Agamben's argument at this point may seem immoderate if not controversial until we consider that the ambition of power in the camps was the banalisation of life: the stripping away of political community (bios politikos) so as to produce 'bare life' - a life beyond political and legal representation. ${ }^{12}$

And it is this banalisation of life, as a crucial first step in the mechanism put in place by a sovereign power, that renders life bare; and it is this mechanism inherent in the sovereign state's deployment of the exception that Agamben compares across the various manifestations of indistinct zones in our present time, and not the degree or vastness of suffering inflicted. He writes:

\footnotetext{
If this is true, if the essence of the camp consists in the materialisation of the state of exception and in the subsequent creation of a space in which bare life and the juridical rule enter into a threshold of indistinction, then we must admit that we find ourselves virtually in the presence of a camp every time such a structure is created, independent of the kinds of crime that are committed there and whatever its denomination and specific topography. ${ }^{13}$
}

For Agamben, then, it is the mechanisms that rendered life banal and that produced the camps that are continuous with, and not contiguous to, political and legal processes in our age; the so-called Schutzhaft, or protective custody, the state of exception that made incarceration in camps legally possible in Nazi Germany, becomes a harbinger for similar mechanisms, which have turned the very notion of exception into a commonplace.

If martial law, or states of exception, at the beginning of the 20th century was proclaimed primarily in reaction to wars and the chaos they wrought, Agamben understands the present-day notion of the exception, beginning with the camps and re-contoured after September 11, 2001, and the ensuing "war on terror", as one

12 Anthony Downey, "Zones of Indistinction: Giorgio Agamben's 'Bare Life' and the Politics of Aesthetics", p. 114. 13 Agamben, Homo Sacer, p. 174 
in which the distinction is increasingly blurred between ordinary law and the law of exception that bans certain groups of people in a purported effort to protect its citizens. Potential terrorists, political prisoners, refugees, torture victims, the vanished-all count among the dispossessed of the late $20^{\text {th }}$ and early $21^{\text {st }}$ centuries, their subject positions in most cases readily recognisable and comforting to those whose own subject positions would appear less vulnerable. In Agamben's more radical proposal, however, we lose the ability to recognise who in fact counts as a homo sacer. ${ }^{14}$ Therefore, as the state of exception has, in Agamben's thinking, become the rule of law in contemporary politics, "we are all virtually homines sacri."15 "Bare life," Agamben concludes, "is no longer confined to a particular place or a definite category. It now dwells in the biological body of every living being." ${ }^{\prime 16}$ If the law of exception has become exemplary of modernity, then what of the modern political subject? Agamben's proposition, that homo sacer dwells in all of us, changes the very idea of what constitutes the modern political subject, who, along with the state of exception, is also no longer the exception, but has instead become emblematic of our times. ${ }^{17}$ And this in turn challenges some of the more dominant master narratives of our era.

Tracing the "ideological confluence between the technologies of the novel and the law that manifests in a common vocabulary and transitive grammar of human personality development,"18 Joseph Slaughter argues that the modern human rights regime as well as international legal conceptions of the modern subject draw from the narrative precepts and social vision laid down by the $19^{\text {th }}$-century Bildungsroman. "The movement of the subject from pure subjection to self-regulation," Slaughter observes in this context,

14 Anna-Maria Smith, "Neo-eugenics: A Feminist Critique of Agamben", https://arcade.stanford.edu/occasion/neo-eugenics-feminist-critique-agamben, accessed May 2018.

15 Agamben, Homo Sacer, p. 115, emphasis mine.

16 Agamben, State of Exception, p. 115.

17 For a lucid discussion of Agamben's state of exception and his notion of bare life, see Anthony Downey, "Zones of Indistinction: Giorgio Agamben's 'Bare Life' and the Politics of Aesthetics" Third Text, Vol. 23, Issue 2, March, Routledge: 2009, p. 109.

18 Joseph Slaughter, Human Rights Inc: The World Novel, Narrative Form and International Law, New York: Fordham University Press, 2007, 4. describes the plot trajectory of the dominant transition narrative of modernisation, which both the Bildungsroman and human rights law take for granted and intensify in their progressive visions of human personality development. ${ }^{19}$

And further, the Bildungsroman and human rights law

are mutually enabling fictions: each projects an image of the human personality that ratifies the other's idealistic visions of the proper relations between the individual and society and the normative career of full and free human personality development. ${ }^{20}$

The figure of homo sacer is antithetical to the imaginary of the post-enlightenment subject cast both in the Bildungsroman and human rights law. The sacred man is granted neither the chance to develop, nor to become a subject fully integrated in his social context; and if Agamben is right, and we have all become potential sacred men, then the narrative trajectory of the modern political subject is in danger of becoming usurped, as is the idealised notion of human rights. For the homines sacri of our time are individuals who are by definition without rights, human or otherwise, at the very moment, when they need them the most. It is this paradox which is inscribed in Agamben's notion of states of exception, and its implications for the relations between sovereign power and bare life; and it is this paradox that we see at work both in Fernando Melgar's Le vol special, where Melgar renders legible the homo sacer in a modern-day Swiss "zone of indistinction", the detention centres where those slated for deportation are held until they are forced to leave on their special flights, as well as in the law on coercive measures from 1995, which made these zones of indistinction possible, and which is the focus below.

19 Slaughter, Human Rights Inc., 9; quoted in Agnes Woolley (2017) "Narrating the 'Asylum Story': Between Literary and Legal Storytelling", Interventions, 3-4.

20 Slaughter, Human Rights Inc., 5. 


\section{Lex Letten or "It's enough for Zurich to have a cold for all of Switzerland to take to bed"21}

The Zurich airport prison where Chiakwa died is, like many prisons, on the edge of town. Unlike other prisons, however, it is divided into two areas, one for short-term incarceration and pretrial detention for "normal" prisoners convicted or accused of a crime, the other to house people slated for forced expulsion, incarcerated either because their bid for asylum has been rejected, or because they are in Switzerland without proper papers-and not because they have committed any crimes as defined under Swiss penal law. ${ }^{22}$ The construction of this facility took place in the early 1990s and was part of the same historical

21 This quote is taken from a statement made by Jean-Claude Zwahlen, as noted in the minutes of parliamentary debate in 1994 . The complete quote reads as follows: "Haste is not a good counsellor. In fact it is enough for Zurich to have a cold for all of Switzerland to go to bed and take a horse-remedy that is probably disproportionate to the cause of the malady." https://www. amtsdruckschriften.bar.admin.ch/viewOrigDoc/20023755. pdf?ID=20023755, p. 93, accessed July 30, 2018, translation mine.

22 https://www.tagesanzeiger.ch/schweiz/standard/ Aus-dem-Innern-des-Ausschaffungsgefaengnisses/ story/31691996. The entire building is an ensemble of square cement blocks built in the mid-1990s, following blueprints of traditional prison architecture. Back in the 1990s, the contemporary practice of expulsion was still in its infancy, the pertinent law in asylum politics having been passed only in December of 1994; the same year, the green light was given to build these new facilities. This had implications for the architecture of the detention prison. As the then-director of the prison, Rico Vincenz, reflected at the time, it was built "before anyone really knew what deportation detention was." Quoted in Monique Ligtenberg, "Endstation Ausschaffungsgefängnis," in Flughafen Kloten: Anatomie eines komplizierten Ortes, Aether Verlag, 2018, p. H7. See this article for an interesting study on the interlacing of discourses around drug policies and migration in the mid-1990s which, she argues, led to the building of the deportation prison. https://aether.ethz.ch/ausgabe/flughafen-kloten-anatomie-eines-komplizierten-ortes/ endstation-ausschaffungsgefaengnis/, accessed July 2010. Accordingly, the sleeping quarters are cells that could be locked at night, the windows barred, the doors had security systems installed, and the premises were under constant surveillance. This prison architecture, based on traditional assumptions about how to treat criminals, continues to define the lives of refugees who await expulsion today, more than twenty-five years later. context as the third revision of the Swiss Ausländergesetz, or law on foreign nationals. ${ }^{23}$ Both the law and the prison were a result, at least indirectly, of the open drug scene that had, at the time, grown up in some of Switzerland's larger cities. In Zurich it had produced a thriving, but for many deadly, "milieu" in the Letten neighbourhood, an area along the banks of the River Limmat, located not far downstream from the once notorious needle park at Platzspitz, itself closed by police order in 1992. Hence the nickname given the proposed law by some of the parliamentarians who opposed it: Lex Letten. By 1993 public sentiment was at a high pitch, not only in Zurich itself but throughout the country, stoked by intense media coverage which, as historian Monique Ligtenberg shows, had, under the deft tutelage of the right-wing parties ${ }^{24}$, gradually shifted from a story about those taking drugs to those dealing them, many of whom came from outside of Switzerland, some of them asylum seekers. ${ }^{25}$ The problem had thus mutated in the minds of many from a drug problem into an Ausländerproblem, a problem with foreign nationals. The perception that a presumed threat to a country's body politic emanates from foreigners is common to many nations; in Switzerland this fear manifested itself periodically throughout the 20th century, for instance in fears of Verjudung, or "Jewification", in the 1930s and 1940s, and in concerns about Überfremdung, or "over-foreignization", in the late 1960s and early 1970s, a narrative fuelled by a marked increase of mainly Italian guest workers, which in turn inspired the "Schwarzenbach-Initiative", which proposed delimiting migration in a popular vote in June of

23 So-called Ausschaffungshaft, detention for forced expulsion, for rejected asylum seekers was first introduced on June 20, 1986 by parliament. While people could be detained by the police for up to 48 hours under this regulation, any detention past 48 hours had to be confirmed by a judge, and under no circumstances could detention last longer than 30 days. See https://www.bger.ch/files/live/ sites/bger/files/pdf/de/bericht_hugi_yar_version_internet.pdf, p. 3. accessed January 15, 2019.

24 These included principally the far-right Swiss Democrats and the Schweizerische Volkspartei (SVP) or Swiss People's Party.

25 Ligtenberg "Endstation Ausschaffungsgefängnis," p. H7., https://aether.ethz.ch/ausgabe/flughafen-klotenanatomie-eines-komplizierten-ortes/endstation-ausschaffungsgefaengnis/, accessed July 2018. 
$1970 .{ }^{26}$ By the early 1990s, questions revolving around Swiss Ausländerpolitik had, as elsewhere, become a central element of the populist platform. The problem of drug abuse in the 1990s, twinned in the imaginary with the perceived threat of foreigners, had parts of the country in what some considered a state of emergency. This, in turn, put enormous pressure on politicians and the government to create legal instruments that promised quick solutions. The result of this pressure was indeed a cascade of measures, not, however, in the area of drug policy, as might have been expected, but rather in laws governing foreign nationals, beginning with the Federal Act on Coercive Measures mentioned above ${ }^{27}$ and the decisions to build deportation centres, including the deportation prison at the Zurich airport, and to implement forced deportations on special flights. A narrative slippage had thus occurred, which resulted in legal measures papering over a more complex social malaise: rather than addressing the deeper rooted domestic problems at the heart of the drug scene, such as alienation, a hidden class system and the very real disease of addiction, the politicians focused instead on the usual suspects, "delinquent" foreigners, who had neither a voice nor a vote, and whose expulsion was made to sound like the logical solution.

26 Forarecentrecapofthisinitiative, seeforinstancehttps:// www.nzz.ch/schweiz/schweizer-geschichte/als-jamesschwarzenbach-die-auslaenderpolitik-entdeckte1.18430680, accessed January 10, 2019.

27 In particular, the law was to introduce four new articles: $13 a$, which states that, during the deliberations on a request for asylum, a person can be held in so-called Vorbereitungshaft, or preparatory detention, for up to three months if he or she has committed infractions against the law; 13b, which states that, if a request for asylum is denied, he or she can be detained for up to 12 months in so-called Ausschaffungshaft or detention for expulsion in cases in which it is feared that the asylum seeker will resist implementation; 13c, which states that the deportation is to be ordered by an official of a canton, to be confirmed no more than 96 hours later by a judge; and 13e, which states that foreigners without proper papers can be denied entry to, or may be forced to exit from, particular areas by cantonal officials if they disturb or threaten security and order. Furthermore, youths from the age of 15 can be treated as adults, and the police can raid apartments without a warrant if they suspected the presence of "illegal refugees" or the papers of "illegal refugees". See Art. 69-71, Schweizerisches Ausländergesetz; see also https://www.bger. ch/files/live/sites/bger/files/pdf/de/bericht_hugi_yar_version_internet.pdf, accessed January, 2019.
The law on coercive measures was initiated by the then-Federal Councilor and Minister of Justice Arnold Koller in late 1993 as the third revision to the asylum law, and was the first to introduce a number of calibrated measures of forced detention for asylum seekers and foreigners not in possession of the requisite papers. It was taken up in parliamentary debate in December of 1993 as part of an accelerated legislative procedure. The Federal Council issued its Botschaft, or official proclamation to parliament, on December 22, 1993 , with a draft of the new law for consultation and revision in March of 1994, with the following statement:

Even though the number of asylum seekers decreased markedly last year and 1993 has not seen an excessive increase, the topic of asylum remains a political issue of the first order. The broad public has for quite some time now been preoccupied with the problem of asylum seekers in the drug scene who have dealt drugs under protection of the asylum law. The abuse of the right to hospitality, which Switzerland grants those who are politically persecuted, by a minority of delinquent foreigners, and the problems presented to officials in the implementation of deportation procedures, even of those asylum seekers and foreigners who were rejected legally, have increasingly led to calls for tightened legal measures. ${ }^{28}$

\section{And further:}

In the conviction that we must confront abuse resolutely, and that we should advance the fight against criminality in the area of asylum and foreigners using all legally admissible and suitable means, the proposals worked up by the expert commission will be separated from the regular revision of the AVB (Bundesbeschluss über das Asylverfahren [Federal Decision on the Asylum Process]) and introduced in an accelerated legal proceeding. This will likely allow us to enforce the measures by July $1,1994 .^{29}$

Striking in this context is that a relatively contained situation-the drug scene in a few Swiss cities-had not only been re-conceptualised, in the media of the time, as a problem having to do with foreigners, rather than with local drug

28 Botschaft zum Bundesgesetz über Zwangsmassnahmen im Ausländerrecht, in 4th Bundesblatt, 46. Jahrgang, Band 1 , p. 306, translation mine: https://www.amtsdruckschriften.bar.admin.ch/viewOrigDoc.do?id=10052908 accessed July $1,2018$.

29 Ibid, p. 1, translation mine. 
policies or domestic issues, but that, due to this narrative shift, the drug crisis in Zurich was actually steering legislative proceedings in the area of foreign nationals.

The law's ambiguities and potential threat to principles of human rights did not elude the members of parliament, mainly on the left, who were called upon to consult on it in the spring parliamentary session of 1994, while those on the right generally agreed with its premises. ${ }^{30}$ Cécile Bühlmann of the Green Party in Lucerne, for instance, pointed to the massive increase in the amount of time people could be detained under the new law: under the existing law, refugees who had been denied asylum could be detained for up to 30 days if there were concerns that they might go into hiding, while the new law allowed for preparatory detention of up to three months, seamlessly followed by deportation detention of up to six months, which could be extended for another six months-an increase of 14 months compared to the previous law. "That's how long people who have committed no crime under our penal law can be deprived of their freedom! ... Forcible detention," Bühlmann concluded, "is a drastic encroachment upon the rights of individuals, and for this reason we need to be extremely careful in this area." ${ }^{\prime 31}$ Bühlmann also noted the fact that it was the so-called Fremdenpolizei, or foreigners' police, and not a judge, who could determine this detention, judges only being required to confirm the decision a posteriori. ${ }^{32}$ Paul Rechsteiner, Social Democrat and then-President of the Swiss Federation of Trade Unions, criticised the proposed law as an example of a new mode in lawmaking, in which politics is put under pressure by media campaigns orchestrated by the right, and then tries to alleviate that pressure by creating a proposal for a new law, "which severely limits the human rights of people with a foreign nationality ... as though the nasty foreigners were

30 For an overview of the parties represented in the Swiss Parliament, see https://www.parlament.ch/en/organe/ groups/parties-in-parliament, accessed January 20, 2018.

31 https://www.amtsdruckschriften.bar.admin.ch/view OrigDoc/20023755.pdf?ID=20023755, p. 100, accessed July 15,2018 , translation mine.

32 https://www.amtsdruckschriften.bar.admin.ch/view OrigDoc/20023755.pdf?ID $=20023755$, p. 103, accessed July 15,2018 , translation mine. to blame for the drug misery in Zürich". ${ }^{33}$ In the meantime, Rechsteiner continued, "the question of whether the coercion law does not abet racism, governmentally decreed racism, is not a topic of discussion, at least not an official one." ${ }^{\prime \prime 4}$ Others, like the Social Democrat Francois Borel from Neuchâtel, observed that the law fails to distinguish between people who do not possess the right kind of papers, and those who are "delinquent", thus erasing the difference among those foreigners who merely lack papers, those who commit criminal acts, and all other foreigners. "Certainly," he said,

tourists and asylum seekers who-and here I cite the law-'do not possess a regularresidence permit' are not illegal because of it. On the other hand, to put those one thinks are drug dealers in the same boat as those one imagines to be too frightened to return to their country to accept a decision of expulsion from our authorities is not admissible. In both cases, drugs or the refusal of expulsion, they risk preventative imprisonment without having committed any crimes. ${ }^{35}$

Moreover, Borel continued, "the problem in Zurich is a management problem. We have a penal law and an administrative law, both of which could be applied to resolve acute problems." ${ }^{36}$ Parliamentarians on the right, in the meantime, spoke up in favour of the law, and Rudolf Keller, a member of the right-wing Swiss Democrats, thanked Federal Councillor Koller-who was not amused-for his efforts at the end of the four-day deliberation:

Despite the watering down of the law, I thank you, Mr Federal Councillor, for proposing the law in this form, among other things, due to the pressure the Swiss Democrats have exerted over years. ${ }^{37}$

33 https://www.amtsdruckschriften.bar.admin.ch/view OrigDoc/20023754.pdf?ID=20023754, p. 80, accessed July15, 2018, translation mine.

34 https://www.amtsdruckschriften.bar.admin.ch/view OrigDoc/20023754.pdf?ID=20023754, p. 80, accessedJuly15, 2018, translation mine.

35 https://www.amtsdruckschriften.bar.admin.ch/view OrigDoc/20023754.pdf?ID=20023754,p. 78, accessedJuly15, 2018, translation mine.

36 https://www.amtsdruckschriften.bar.admin.ch/view OrigDoc/20023754.pdf?ID=20023754,p. 78, accessedJuly15, 2018, translation mine.

37 https://www.amtsdruckschriften.bar.admin.ch/view OrigDoc/20023758.pdf?ID=20023758, p. 153, translation mine. 
In the end, the law passed parliament with a twothirds majority. When it came before the people in December of 1994, an overwhelming $72 \%$ of voters approved it, and it went into force in February of $1995 .{ }^{38}$

A number of points are worth stressing: first of all, as suggested by Rechsteiner, the category of "race", and with it racism, is central, albeit typically unarticulated, in the discourse surrounding refugees and asylum in Switzerland and elsewhere. For many in Switzerland today, and even more so in the 1990s, "race" remains a non-existent social category, even against the background of the well-established implications of colonialism. The fact that Switzerland had for a long time been thought to have had little involvement with the colonialist project, and had therefore been sheltered from the global, economic and ethical consequences of post-colonialism, has allowed many to believe that racialised hierarchies do not exist in Swiss society. ${ }^{39}$ Secondly, the law on coercive measures appears to have arisen as a partial answer to a very specific socio-cultural problem: the open drug scene in individual Swiss cities. That drug scene, however, was only marginally related to the situation of asylum seekers in Switzerland. In that sense, the law might be read more as a diagnostic than as a corrective tool, a reading that reveals multiple layers of what was at stake culturally at that moment in time:

38 In a fourth revision of the Asylum law of 2006, the maximal time of incarceration was doubled from 12 months to 24 months with the addition of the so-called Durchsetzungshaft, also known as Beugehaft, or coercive detention, although when Switzerland entered the Schengen area, it was forced to reduce the maximal time of incarceration to 18 months to accord with the EU policy. Depending on the circumstances in the home countries of refugees, the deportation itself at times also goes against the Swiss constitution, article 25, which reads: "Refugees may not be deported or extradited to a state where they are persecuted; and no one may be deported to a state where they are threatened by torture, or any other kind of cruel or inhumane treatment or punishment." (Translation mine.)

39 See Purtschert, Patricia, Barbara Lüthi and Francesca Falk (eds) (2012), Postkoloniale Schweiz: Formen und Folgen eines Kolonialismus ohne Kolonien (Bielefeld: Transcript). See also Michel, Noémi, and Manuela Honegger (2010) 'Thinking Whiteness in French and Swiss Cyberspaces', Social Politics, 17 (4): 423-49; Lavanchy, Anne (2013b) 'L'amour aux services de l'état civil: Régulations institutionnelles de l'intimité et fabrique de la ressemblance nationale en Suisse', Migration sociétés, 25 (150): 61-94. namely, a perceived threat to order and security, but also to a hitherto stable national identity.

The drug crisis, meanwhile, however distressing, did not adequately explain the perceived threat to national identity. Recall that Switzerland in the 1990s faced more than an epidemic of drug-related deaths; its very self-understanding as a nation was being destabilised by the beginning of a re-evaluation of Switzerland's role during World War II, in particular, the assessment of its restrictive refugee policies with regard to Jewish refugees and the handling of dormant bank accounts. ${ }^{40}$ Hence, while it was the open drug scene that was addressed in the 1995 law on coercive measures, the cultural processes driving this reckoning with the past provided a further, and in many ways more resonant, motor for the symbolic tightening of the borders. From a narrative point of view, we might think of the early 1990s as a battlefield of shifting stories about the nation and about national identity, on which the more traditional telling of the effectiveness of Swiss resistance during the war, and the country's humanitarian readiness to help those in need, was being challenged by narratives about self-serving negotiations with the Third Reich, and about the fateful decisions to close its borders to Jewish refugees on August 13, 1942-a decision driven by a wide-spread anti-Semitism within the government that cost many thousand Jewish refugees their lives. ${ }^{41}$

40 This re-evaluation would culminate in an official apology by the then-President of the Federal Council, Kaspar Villiger, on the occasion of the 50th anniversary of the end of World War II in 1995. This apology in turn would be followed by the creation of the Volcker Commission in 1996 to investigate the dormant accounts of Jews persecuted during WWII, for which the two banks UBS and Credit Suisse ended up paying a settlement of 1.25 billion dollars in 1998. It also led to the creation of the Bergier Commission, also in 1996, to investigate assets, economic relations, arms production and the situation of Jewish refugees during WWII. All three of these events-the public apology, the formation of the Volcker commission and the creation of the Bergier commission-were met with consternation by the right wing of the government and broad swaths of the population. In other words, the open drug scene and the acts of coming to terms with the past presented for many a threat to what it meant to be Swiss.

41 See in particular volume 17 of the so-called Bergier Report, "Switzerland and the refugees during National Socialism", published in 2002: https://www.uek.ch/en/_synthese.htm, accessed January 2019. 
The winners of this battle of narratives in the 1990s were certain politicians, the proposed law itself, and a readership willing to accept the story that law had spun. The national imaginary-the stories that had shaped Switzerland in the postwar era, and that were being stirred up at the time-helped make the legal story both believable and desirable. As Jerome Bruner and Anthony Amsterdam note,

reasoning within the law depends not only on specific states of facts, but also upon the notion of things generally. [...] However we conceive of them, they are grounded in what our culture designates as mattering. And what does and doesn't matter to a country can be traced back though the country's stories, its genres and its enduring myths. ${ }^{42}$

In this particular case, the myth of the dangerous foreigner mattered more than the myth of the humanitarian state, even as-or precisely because-that dangerous foreigner, in the imaginary figure of "the Jew", kept out of the country some fifty years previously, was coming back to haunt the carefully constructed story of Swiss identity forged after the war.

The voices muted entirely by this process, then as now, are those of the actual foreigners in question, rejected asylum seekers by definition without recourse to a safe haven. These are the refugees whose stories of persecution accorded neither with the inflexible plot line sought by the officials deciding on asylum protection, nor with the definition of refugees laid out in the 1951 Convention Relating to the Status of Refugees and the 1967 Protocol that followed. In these texts, the UN defines the refugee as someone who has a "well-founded fear of persecution for reasons of race, religion, nationality, membership of a particular social group or political opinion." ${ }^{\prime 3}$ As Alexander Betts and Paul Collier argue, this definition goes back to a US American narrative constructed in the early 1950s, at the height of the Cold War, and tailored to the situation of would-be defec-

42 Amsterdam, Anthony and Jerome Bruner, Minding the Law, Cambridge: Harvard University Press, p. 111 (emphasis in the original).

43 See the UNHCR text of the 1951 Convention Relating to the Status of Refugees, https://www.unhcr.org/3b66c2aa10, accessed January 7, 2019. tors behind the Iron Curtain. ${ }^{44}$ Today's refugees, who are often fleeing civil wars, abject poverty or environmental crises, but who are not victims of racial, religious or other forms of personal persecution, may have good reason to leave their homes, but no longer fit the Cold War definition of a refugee; their stories, accordingly, do not ring true. The stateless foreigners in this particular Swiss legal story of coercive measures are not deemed worthy of refugee status based on their particular stories. Rather, they are rendered illegitimate and muted, homines sacri, a threat to civil society. Set up in this manner by the legal and cultural narratives prevailing at the time of the law's ratification, the coercive measures planned for the deportation of rejected asylum seekers seem less draconian; the human rights violation the law constitutes seems justified by its end, which is to shape a legal instrument to remove undesirables and restore safety to the streets of Switzerland.

How can this scenario be thought with Agambens notion of the state of emergency? While the "war on drugs", which led to the legislation's drafting in 1995, could not officially be declared a national state of emergency along the lines of Agamben's formulation, because only a few cities were affected by it; that law was nonetheless introduced as an accelerated legislative procedure out of sync with the ordinary cycle of revisions to the law on foreigners. In other words, a state of exception was invoked not formally, but circumstantially, and presented as such to the public in populist rhetoric in the form of ads and media coverage before the vote on the law on coercion was held. The official legitimation for the law derived from the argument that foreigners and asylum seekers were endangering national order and security; a more layered reading of the cultural environment in the early to mid-1990s suggests that the pressure to create coercive measures was based more urgently on the sense that Switzerland's national identity was under siege by a past coming back to haunt it. This perceived endangerment, on both the literal and the symbolic levels, was then translated into some of the more extreme measures foreseen by

44 Betts, Alexander and Paul Collier, Refuge: Transforming a Broken Refugee System, Oxford: Oxford University Press, 2017. 
the law to impose order by carving up, delimiting and transforming the spaces foreigners, perceived as dangerous, could inhabit. This took the form of a massive increase of time in detention for rejected asylum seekers to ensure the smooth expulsion from the national space; of the institution of special flights; of the banning of suspected drug dealers with foreign nationalities from, or their containment within, certain areas; and of the diminishment of the role of judges and lawyers in the various processes, and the concomitant augmentation of the role of administrators. Each of these strategies resulted in a decrease of recourse to the law for those affected, effectively stripping rejected refugees of their subjecthood under the law, and turning them into homines sacri.

\section{Le Vol Spécial: Screening Bare Life}

Le vol spécial, made almost twenty years after the 1995 law on coercive measures was first passed, shows the practical consequences of that law in daily life at the Centre Frambois, near Geneva, one of 28 so-called Ausschaffungszentren, or deportation sites, in Switzerland. The documentary translates the dry legal text of the coercive measures, which suspend the right to residency, the ability to move around freely and to have one's story heard, into a visual language demonstrating what it means when people are forced to move between zoe, bare life, and bios, political life. Revolving around the conditions of incarceration and the inmates' stories, the film evokes dichotomies of surveillance and revelation, systemic power hierarchies, human rights and the mechanisms of the expulsion narrative. In so doing, Le vol spécial helps to understand often hidden aspects of today's asylum regime and offers a commentary on the Swiss institution of forced deportation from the inside out. It also proposes a practical application of Agamben's notions of sovereign power and bare life. ${ }^{45}$ The

45 Critics of Agamben point out that in his ambitious project of establishing a sweeping socio-political theory of all the Western modes of governance over the centuries, he has failed to take account of context-specific, essentializ-
20 to 25 inhabitants of the Centre Frambois are all men; those portrayed in the film are mainly from African countries, and two from Kosovo. The inmates are there for one reason alone: to be forcibly sent back to their native countries at the end of the administrative process that will wrap up their individual cases. They are all either asylum seekers whose asylum requests have been rejected by the Swiss administration, or who have spent time in Switzerland as sans-papiers, people lacking official documentation, who either never applied for asylum or who went underground after being rejected, and were subsequently picked up by the police. All the individuals, furthermore, have been detained without a court conviction, many following an administrative process that was confirmed only after the fact by a judge. ${ }^{46}$

ing structures that produce bare life on the basis of identity markers such as gender, class, ability and race, and that he has failed to look closely at the variety of forms bare life can take within the context of different political regimes. Taking the situation of the "welfare mother" in the United States as her example, political theorist Anna-Marie Smith, for instance, points out that by adducing only the very extreme cases-the inmates in Nazi concentration camps or the prisoners in Guantanamo Bay-and by proposing a sweeping, ahistorical theory, Agamben "completely fails to grasp the centrality of gender to the biopolitical project of producing bare life." See Anna Marie Smith, "Neoeugenics: A Feminist Critique of Agamben." Occasion: Interdisciplinary Studies in the Humanities v. 2 (December 20, 2010), http://occasion.stanford.edu/node/59, 2-9, accessed June 2018.

Judith Butler, in Precarious Life: The Powers of Mourning and Violence, similarly critiques the lack of specificity in Agamben's conceptualization of power, writing that the broad claim that we are all potentially homines sacri tells us very little about how power in fact operates, "how sovereignty ... works by differentiating populations on the basis of ethnicity and race..." In other words, Butler is much more interested in the nuances of what makes life liveable (and mournable). Her idea of the "precarious body", in this sense, is cultural and political-focused on the things we do to survive, the performances we give so as to adhere to the social protocols of race, sexuality, ethnicity and ability. Agamben's arguments about "bare life", by contrast, are legal-his interests are driven by a will to critique and overcome the law and its function within the sovereign state. See Judith Butler, Precarious Life: The Powers of Mourning and Violence. New York: Routledge, 2004, 67-68.

46 Seehttps://www.bger.ch/files/live/sites/bger/files/pdf/ de/bericht_hugi_yar_version_internet.pdf, accessed January 15, 2019. 
The documentary begins with an introduction to Ragip, a man from Kosovo who had worked in Switzerland for 22 years as a seasonal worker. $\mathrm{He}$ and his family are classified as sans-papiers, without rights to residency. The film's opening sequence captures the moment in which Ragip is told about his imminent deportation, and the viewer learns what in fact constitutes a special flight. ${ }^{47}$ We learn not only of the hopeless situation of Ragip, and by extension of all the inmates at Frambois, and the forced choices they are presented with by the logic of deportations: either go voluntarily, with some dignity, or involuntarily, on a special flight, bound up and accompanied by police. By casting us into an intimate setting with Ragip and his guard-an intimacy emphasised by the camera's mid-level close-up-this first scene of Le vol spécial also brings into focus the representational anxieties that beset the documentation of bare life. Melgar, together with his camera crew, spent some nine months in the centre in 2010, filming several hundred hours of footage. The filmmaker and the crew remain entirely invisible, the only narrative we can discern shaped in the editing process, through the stories told by those filmed, and the events that unfold during the filming itself. With this radical omnipresence of the visual recording, twinned by the total absence of narrative voice-over, the documentary achieves a seeming indifference to the camera on the part of those filmed, which translates into an equivalent lack of awareness, on the part of the viewer, of the way the story itself is shaped. This indifference renders the filmmaker, and the power of the cinematic gaze, largely invisible, and as viewers, we feel at times as though we are watching through surveillance cameras, voyeur-like. This documentary style raises a number of questions: What does it mean for refugees and asylum seekers to be filmed this way during a vulnerable, life-altering situation? Is this an appropriation and exploitation of someone's story, which, however well-intentioned, colludes with some of the bio-political technologies used to further marginalise refugees? What does it mean for the filmmaker and his team to remain invisible, with their-and our-power

47 See Fernand Melgar, Le vol spécial on vimeo: https:// vimeo.com/111191661, 00:18-5:51, accessed February 1, 2019. removed from the visual equation? And finally: is the screening of the inhabitants and their stories a further purloining of rights, or is it, as Melgar would have it, a chance for the inmates at Frambois to have a voice, and to be able to speak about the conditions of their incarceration and deportations to one another, to the guards, and to a larger public long after they have dropped out of the official narrative cycle?

The portrayal of bare life, as art historian T.J. Demos argues in his book The Migrant Image, is ethically complex:

The documentary representation, when it does take on
a relation to bare life, often serves the interests of the
state, according to which photography, positioned in
ever-new and expanding surveillance systems, oper-
ates as judicial and forensic evidence wherein 'truth'
and 'evidence' live on through their continual institu-
tional and legal validation. Indeed the documentation
of bare life, it appears, is closely aligned to the exer-
cise of biopower. ${ }^{48}$

Given this use of the documentary form to work against those who are marginalised, it is an interesting move by Melgar to use the veracity claims that usually inhere in the genre of the documentary to support, for once, the testimonial efforts of the marginalised, in this case the rejected asylum seekers. Le vol spécial uses the documentary form, traditionally a tool of the oppressor, to actually reveal the kind of oppression and violence experienced by the inmates of these centres, and to give them a voice that most homines sacri do not possess. Indeed, the documentary depiction of the ever-shifting legal decisions that swirl around these men's lives and can abruptly change their fates also fleshes out Agamben's rather vague description of "the indistinction between outside and inside, exclusion and inclusion" quoted above and renders the documentary narrative a potent political tool. ${ }^{49}$

The politics of narrative takes centre stage in Le vol spécial: in the depiction of the inmate's stories, in the stories to which the inmates refer, in the stories told by the guards and care-givers, as well as in the significance of special flights as a story in the larger Swiss cultural realm. In terms

48 T. J. Demos, The Migrant Image: The Art and Politics of Documentary During Global Crisis, Combined Academic Publication, 2013, p. 99.

49 Agamben, Homo Sacer, 27 
of the inmate's stories, one striking feature of the documentary is that, while we get to see the would-be refugees in unguarded moments and hear parts of their stories, these are often truncated or silenced or interrupted by those around them. The police and care-takers who speak to them most often cut them off when they try to recount their reasons for coming to Switzerland, for not wanting, or not being able, to go back to their countries of origin, or for wanting to stay in Switzerland. Each level of bureaucrat or policeman or care-giver has a different, carefully circumscribed role: to care for the physical well-being of the inmates in the centre and to make sure transitions are smooth and nerves are calmed; to accompany those to be deported to the airport; to shackle them; to deport them; but not to hear or evaluate or judge their stories anew once a decision has been handed down.

In other words, the refugees in deportation centres are done telling stories as far as those in charge are concerned, their initial attempts when they first arrived having been found to be illegitimate, or unauthentic; in any case, not to meet the definitional standard of a refugee deemed worthy of asylum. What the documentary shows us very eloquently, then, is that the homo sacer is essentially rendered mute, story-less, deprived of the most basic human right to tell a story, and hence shape a life. In fact, being story-less can be understood as a central feature of bare life; inherent in the production of bare life is the removal of individuals from the story-telling cycle that might change their future. What happens to the ability to tell stories in this Swiss "zone of indistinction" is perhaps the fundamental narrative of this documentary. While the documentary might be accused of purloining the images of the prisoners, of taking their stories to be shown to unseen audiences across Switzerland and beyond, it serves at the same time as a vehicle to restore the ability to tell these stories. Insofar as the ability to tell stories, to have a voice and to enjoy freedom of expression are defining features of citizenship, Le vol spécial attempts to repair the status of the sacred man to that of man, and to defy the power of the sovereign to silence him. In that sense, Le vol spécial also adds a muchneeded corrective to the story Switzerland tells about its own status as a humanitarian nation.
The documentary also shows a clear understanding on the part of the inmates of the cultural mechanisms and the racist narratives that put them there. Take for instance a scene that features a conversation between some of the inmates at Frambois and one of their guards, Denis. ${ }^{50}$ The quality of the scene is intimate, underlining not only the close quarters, but also the relations of confidence between guard and inmate, even in discussing the system that forces them into the role of oppressed and oppressor and which suggests that, to a certain degree, both sides are victims of the coercion the law legitimises. It also shows that everyone is quite aware of how the system works publicly to disenfranchise foreigners politically-to paraphrase one of the inmates, people can be locked away for up to 24 months, until they go crazy and can be pronounced dangerous to society. To put it somewhat differently, their discussion traces the intersection of sovereign power with modern techniques for producing the biopolitical body. This scene invokes the SVP's infamous sheep poster, used in its Initiative für die Ausschaffung krimineller Ausländer, ${ }^{51}$ a bill calling for the expulsion of "criminal" foreigners: "When I saw Swiss planes passing over my head when I was eight I thought it was a peaceful country, but once you're here reality is totally different," he says and continues: "When I came here, I asked my brother: who are the black sheep? He said: 'It's people, it's us.' To stigmatise us." ${ }^{25}$ The inmate's remark positions the documentary within the larger panoply of political representational strategies in the area of asylum seekers and refugees in Switzerland. ${ }^{53}$ It also moves the narrative told within the context of detention into the context of those told outside, preparing the viewer for a dramatic clash of narratives-the

50 Ibid, 25:50-28:41.

51 The poster shows four white sheep on a stylised map of Switzerland kicking out a black sheep. For an image of the sheep poster and a brief commentary in the mainstream press on how it is being recycled, see https://www.tagesanzeiger.ch/schweiz/Das-SVPSchaf-reist-um-die-Welt/ story/24832616, accessed January 15, 2019.

52 Fernand Melgar, Le vol spécial, 28:07-28:17 https:// vimeo.com/111191661, accessed August 31, 2018.

53 For an explanation of this initiative, please see the official federal administrative site: https://www.bk.admin. ch/ch/d/pore/vi/vis357t.html, accessed January 2019. This initiative was approved by $52.9 \%$ of the Swiss voting public on 28 November, 2010. 
narrative of the sacred man closed off in Frambois, the soothing narratives told within the centre to enable smooth operations, and the narrative told by the Swiss media against the story of a humanitarian Switzerland.

The scene begins in an office, where the director of the centre informs two of the inmates, Emmanuel and Julius, that their special flight to Nigeria is to take place that very afternoon. We watch Emmanuel and Julius react with dignity to the news, pack up their belongings, hug the director and the guards, get in a bus accompanied by police, and turn the final bend in the road, headed for the airport prison in Zurich, where they will be prepared for the special flight. As viewers, we are also told that no cameras are allowed in the prison in Zurich, and that this will be our final encounter with these two inmates. The whole process is enveloped in a calm and calming story on the part of the director. "Today is the day of your departure," he announces to them, and continues:

We are very sorry to see you go, but I think this is a project for you. It's better that this has an end. We wish you the best of luck for what comes, because you are good men and deserve it. ... First you'll be driven to Lausanne, then in Zurich you will be chained up, it's a special flight. It'll go well. ${ }^{54}$

It is a story that puts a civil stamp on the inherent violence of the practice of deportation; one that eases the task of the director, to run a humane operation and send his inmates to an uncertain future. As a viewer, it is comforting to see the way this is handled, without outbursts or protests on the part of the prisoners, the social contract built up between director, guards and inmates smoothing over the inherent hierarchy of power and normalising the violence lurking just below the surface of the deportation centre.

Into this controlled narrative bursts the national news broadcast in the very next scene, with images of Emmanuel and Julius flashing across the screen as the newscaster announces the death of Joseph Ndukaku Chiakwa, slated for the same special flight headed for Nigeria as Emanuel and Julius had been. ${ }^{55}$ The news reporter gives a brief account of how special flights are

54 Melgar, Le vol spécial, 1:27:42-1:30:42

55 Melgar, Le vol spécial, 1:30.42-1:31:40 handled, showing the straps and masks used to contain the prisoners, and offering a glimpse of a prisoner, strapped into a chair, as he is carried onto the airplane. Gone is the credibility of the centre's director and care-givers, who have insisted throughout that-often, contrary to the inmate's own fears-all is for the best, and that the dignity of the people being deported is guaranteed; gone too is our confidence in the institution of the special flight. The soothing assurances, it turns out, are a fiction the director and care-givers rely on to be able to do their job. ${ }^{56}$ It is part of a discourse through which the degrading events at the centre can be normalised and humanised. In that sense, the narrative tug-ofwar in Frambois is revealed as a microcosm of the narrative tug-of-war on the national level, in which the story of humanitarian benevolence competes with that inscribed in inhumane asylum practices.

This moment also confronts us with the multi-layered power differentials inherent in asylum politics. At the same time as we see the clash of framing conventions between the official news story and the centre's story concerning the deportation practice, one speaking truth to the other, we also witness the breakdown of the discursive harmony between the inmates and their guards: there can be no talk of dignity, calm and respect at this point, and all the sincere promises of the guards and the director are suddenly revealed as part of a rote human rights discourse with little meaning or basis in truth. The director's statement, that he will intervene with the president of the foundation that runs the deportation centre to demand humane treatment for his inmates, reveals the shadowy outlines of a much larger power apparatus propelling the institution of forced deportation, and rendering those who implement the system mere cogs in a machine. The director's statement to the assembled inmates, moreover, that he is no longer proud to be a Swiss, contains a rather stale definition of Swiss identity dependent on ideals of humanitarianism that have slowly crumbled, over the last

56 See Fernand Melgar's 2013 follow-up video to Le vol spécial, entitled The world is like this, in which he follows five of the protagonists in their post-deportation lives in Kosovo, Senegal, Gambia and Cameroon: https://vimeo. com/109008609, accessed January 2019. 
two decades, under the weight of the administrative and legal proceedings of which he is a part. The inmates' narratives at this moment are the ones that offer most clarity. "If it had been a Swiss who died yesterday," Ebrima, one of the men assembled says, "all hell would have broken loose. But because it was an African, nothing much will happen." And Abdoul adds: "Because we are foreigners, we are more exposed than others. To deport someone, it is not necessary to kill them." To the care-giver Denis's fervent assurances that things cannot go on and will certainly change because of this death, he retorts:

We just came to find a better future here. Why? Because you came to Africa and destroyed everything, leaving wars behind. So we come here to seek a better life, because we're human beings like you. But you don't want to accept us here, so sooner or later we will go back. But nothing will change here. ${ }^{57}$

What Abdoul gets wrong here is that he is not, in fact, considered a human being like Denis, because, unlike Denis, he does not hold Swiss nationality. He does not possess, to use Hanna Arendt's famous phrase, "the right to have rights", ${ }^{58}$ which paradoxically tends to be withdrawn at the moment the need for rights is at its greatest, namely when a person loses national

57 Melgar. Le vol spécial, 1:33:32-1:35:50, accessed January 15, 2019.

58 Hannah Arendt, The Origins of Totalitarianism, New York: Harcourt, Brace Yovanovich, (1951) 1968, p. 177. The full quotation from which the phrase is taken appears in Arendt's discussion and reads as follows: "Something much more fundamental than freedom and justice, which are rights of citizens, is at stake when belonging to a community into which one is born is no longer a matter of course and not belonging is no longer a matter of choice, or when one is placed in a situation where, unless he commits a crime, his treatment by others does not depend on what he does or does not do. This extremity, and nothing else, is the situation of people deprived of human rights. They are deprived, not of the right to freedom but of the right to action; not of the right to think whatever they please, but of the right to opinion. Privileges in some cases, injustices in most, blessings and doom are meted out to them according to accident and without any relation whatsoever to what they do, did, or may do. We become aware of the existence of a right to have rights (and that means to live in a framework where one is judged by one's actions and opinions) and a right to belong to some kind of organised community, only when millions of people emerge who have lost and could not regain these rights because of the new global situation" (emphasis mine). protection. The inalienable rights proposed by the Universal Declaration of Human Rights (UDHR) as the property of all human beings simply on the grounds of being human turn out in the end to be mere fiction. Refugees and asylum seekers, Agamben suggests, are so disquieting to the notion of the nation, primarily because by "breaking the continuity between man and citizen, nativity and nationality", ${ }^{59}$ they upset the fiction of the modern nation-state, which rests on the idea that birth itself, via the alchemies of ius sanguinis and ius soli, equals citizenship, which in turn equals nation. ${ }^{60}$

Returning once more to the distinction between zoe, natural life, and bios, political life, this last scene helps us understand bare life as an exposed, politicised form of zoe. As philosopher Catherine Mills writes: "Being neither zoe nor bios, bare life emerges from within this distinction and can be defined as life exposed to death, especially in the form of sovereign violence." 61 In being shown how this violence operates to maintain the very ordinary state of exception that resides at the heart of Switzerland's asylum regime, we, the audience, are prompted to re-think how we might position ourselves vis-àvis the national. The only way out of this seeming aporia, both of bare life and the states of exception, according to Agamben, is a flight forward into a world in which politics is the sphere neither of an end in itself nor of means subordinated to an end; rather, it is the sphere of a pure mediality without end, intended as the field of human action and of human thought. 62

The documentary ends not in "a sphere of pure mediality," but in sober reality, the last scene showing the caregiver, Denis, once again announcing to one of the inmates that his "special flight" would be leaving the next morning.

In the seven years since Le vol spécial was made, the number of people fleeing their homes across the world has reached an all-time high, and border regimes have become critically unsta-

59 Agamben, Homo Sacer, 131.

60 Agamben, Homo Sacer, 129.

61 Catherine Mills, Giorgio Agamben, Internet Encyclopedia of Philosophy, http://www.iep.utm.edu/agamben/, accessed June 2018.

62 Giorgio Agamben, Means Without Ends: Notes on Politics, trans Vincento Binetti and Cesare Casare, London and Minneapolis: University of Minnesota Press 2000, p. 117. 
ble. In Europe, this has led to thousands of deaths in the waters of the Mediterranean, and a perceived state of emergency in many European countries that has fueled deadly deals between the EU, Turkey and Libya. Rather than crumbling, then, narratives of nationalism and nation states have been strengthened, and innovative designs for post-national belonging, which was Agamben's larger project, remain in the realm of utopia. Amid the onslaught of news stories of dinghies sinking in the Mediterranean, of countless, uncounted humans drowning in their quest to reach safer shores, of barriers and walls erected along borders, of refugee children separated from their parents, of people held on remote islands in prison-like conditions, the world drifts closer and closer to a two-tiered society: those with stories and those without; those with rights and those, again in Arendt's words, "without the right to have rights". The story of expulsion, it would seem, is becoming a master narrative of its own, one with the power to replace the fiction of human rights for all.

\section{List of References}

\section{Primary Literature}

Agamben, Giorgio. 1998. Homo Sacer: Sovereign Power and Bare Life, trans. Daniel Heller-Roazen. Stanford, CA: Stanford University Press

Agamben, Giorgio. 2000. Means Without Ends: Notes on Politics, trans Vincento Binetti and Cesare Casare. London and Minneapolis: University of Minnesota Press

Agamben, Giorgio. 2005. State of Exception, trans. Kevin Attell. Chicago and London: The University of Chicago Press.

Arendt, Hannah. (1951) 1968. The Origins of Totalitarianism, New York: Harcourt, Brace Yovanovich.

Botschaft zum Bundesgesetz über Zwangsmassnahmen im Ausländerrecht. 1993. 4. Bundesblatt, 46. Jahrgang, Band 1. Bundesarchiv.

Butler, Judith. 2004. Precarious Life: The Powers of Mourning and Violence. New York: Routledge.

Demos, T.J. 2013. The Migrant Image: The Art and Politics of Documentary During Global Crisis. Combined Academic Publication.

Downey, Anthony. 2009. "Zones of Indistinction: Giorgio Agamben's 'Bare Life' and the Politics of Aesthetics".

Lavanchy, Anne. 2013b. "L'amour aux services de l'état civil: Régulations institutionnelles de l'intimité et fabrique de la ressemblance nationale en Suisse", Migration sociétés, 25 (150): 61-94.
Lavanchy Anne. 2015. Glimpses into the Hearts of Whiteness. In: Purtschert P., Fischer-Tiné H. (eds) Colonial Switzerland. Cambridge Imperial and Post-Colonial Studies Series. Palgrave Macmillan, London.

Ligtenberg, Monique. 2018. "Endstation Ausschaffungsgefängnis," in Flughafen Kloten: Anatomie eines komplizierten Ortes, Aether Verlag.

Melgar, Fernand. 2012. Le vol spécial. https://vimeo. com/111191661.

Melgar, Fernand. 2013. The World is like that. https:// vimeo.com/109008609.

Michel, Noémi, and Manuela Honegger (2010) "Thinking Whiteness in French and Swiss Cyberspaces", Social Politics, 17 (4): 423-49.

Mills, Catherine. Giorgio Agamben, Internet Encyclopaedia of Philosophy, http://www.iep.utm.edu/agamben/.

Purtschert, Patricia, Barbara Lüthi and Francesca Falk (eds). 2012. Postkoloniale Schweiz: Formen und Folgen eines Kolonialismus ohne Kolonien. Bielefeld: Transcript.

Schweizerisches Bundesgesetz. 1994. Online-Amtsdruckschriften: Zwangsmassnahmen im Ausländerrecht. Schweizerisches Bundesarchiv. www. amtsdruckschriften.bar.admin.ch/.

Slaughter, Joseph. 2007. Human Rights Inc: The World Novel, Narrative Form and International Law. New York: Fordham University Press.

Smith, Anna Marie. 2010. "Neo-eugenics: A Feminist Critique of Agamben." Occasion: Interdisciplinary Studies in the Humanities v. 2 http://occasion. stanford.edu/node/59, accessed January 2019.

Schmitt, Carl. 2006. Political Theology. Four Chapters on the Concept of Sovereignty. Chicago, trans. George Schwab. Chicago University Press.

Schmitt, Carl. 2006. Nomos of the Earth in the International Law of the Jus Publicum Europaeum, trans. G.L.Ulmen. Telos Press Publishing.

Woolley, Agnes. 2017. "Narrating the 'Asylum Story': Between Literary and Legal Storytelling", Interventions, 19:3, 376-394, http://eprints.bbk. ac.uk/21157/1/21157.pdf, accessed November 2019.

\section{Secondary Literature}

Augenauf. 2010. http://www.augenauf.ch/ dossiers/70-ausschaffungen/125-joseph-ndukaku-chiakwa-alias-alex-khamma.html, accessed on April 2, 2018.

Federal Act on Foreign Nationals. 1995. Articles 69-71. https://www.admin.ch/opc/en/classified-compilation/20020232/index.html.

Gerny, Daniel. 24.11. 2014. Als James Schwarzenbach die Ausländerpolitik entdeckte. Zürich: Neue Zürcher Zeitung.

Hugo Yar, Thomas. 2006. Treffen der obersten Verwaltungsgerichtshöfe Österreichs, Deutschlands, des Fürstentums Liechtenstein und der Schweiz vom 7./8. September 2006. Zwangsmassnahmen im 
Ausländerrecht. Bundesgericht. https://www.bger.ch/ files/live/sites/bger/files/pdf/de/bericht_hugi_yar_ version_internet.pdf

Independent Commission of Experts Switzerland, National Socialism and the Second World War. Final Report. 2002. Zurich: Pendo Verlag.

Parlamentsdienste. Political Parties Represented in Parliament. https://www.parlament.ch/en/organe/ groups/parties-in-parliament

Schweizerische Eidgenossenschaft. 2010. Eidgenössische Volksinitiative, für die Ausschaffung krimineller
Ausländer (Ausschaffungsinitiative)'. https://www. bk.admin.ch/ch/d/pore/vi/vis357t.html

United Nation High Commissioner for Refugees (UNHCR). 1951. Convention and Protocol Relating to the Status of Refugees. https://www.unhcr.org/3b66c2aa10.

Vonplon, David. 13.8. 2008. Das SVP-Schaf reist um die Welt. Zürich: Tagesanzeiger https://www. tagesanzeiger.ch/schweiz/Das-SVPSchaf-reist-umdie-Welt/story/24832616 